\title{
PRACOWNIK SOCJALNY A NIEOZNACZONE MARGINESY KULTUROWE
}

\begin{abstract}
The social worker on the indefinite cultural margins

In the text at hand, I attempt to illustrate the relationship between the concept of human nature and culturally dominant strategies for constructing the "Other." More to the point, I explore the resulting new challenges for a social worker - particularly in the context of overcoming "colloquial reason" by disclosing the actual structure underlying the social process. This, in fact, is the task of sociology within which social work has a significant role to play.
\end{abstract}

Key words: social worker, cultural margins, familiarity, strangeness, otherness

Pojęcia, jakimi operują aktorzy społeczni i społeczeństwo - jak pisał Ernest Gellner - mogą być traktowane jak instytucje, „stanowią one bowiem, tak jak inne instytucje, rodzaj trwałej ramy, niezależnej od każdego pojedynczego człowieka, w obrębie której mają miejsce indywidualne zachowania" (Gellner 1995: 37). Zdaniem Manuela Castellsa wartość teorii wynika przede wszystkim z jej zdolności do prowokowania i strukturyzowania badań empirycznych. Teoria ma ukazać siły nadające kształt widzialnej rzeczywistości. Interesujące są te teorie, które można owocnie zastosować do badania konkretnych sytuacji. Tylko w ten sposób można wykazać ich wartość. Socjolog pisał w Wieku informacji: „największe nadzieje na zrozumienie społeczeństwa należy wiązać z bardziej cierpliwym podejściem do gromadzenia informacji i budowania teorii” (Castells 2010). W obliczu niezgodności między obserwowaną rzeczywistością a teorią należy zawsze zmieniać teorię zamiast „reinterpretować” rzeczywistość, tak by do niej pasowała, a to oznacza nieustanne korygowanie pojęć.

Fundamentalnym pojęciem dla antropologii filozoficznej i społecznej jest koncepcja ludzkiej natury. Myślę, że z różnorodności i pluralizmu powstałych w dziejach filozofii obrazów człowieka można wywieść i taki, że człowiek ma naturę uwikłaną w historię, a oddziaływanie ,istotowej koncepcji człowieka” było i jest silniejsze niż historii. W tej różnorodności tkwiła siła namysłu człowieka nad sobą samym i nad światem.

Początki nauk społecznych są tego najlepszym dowodem. Nie jest przypadkiem fakt, że ich powstanie i rozwój przypadają na drugą połowę wieku XIX. Był to czas dominacji 
kierunku nazwanego ewolucjonizmem, w którym najważniejszą tezą było założenie o tożsamości ludzkiej natury. Ewolucjoniści społeczni nie twierdzili, że jesteśmy tacy sami, lecz że w tym wielkim zróżnicowaniu musi być coś, co nas łączy, co stanowi arche, czyli prazasadę. Owo arche to - ich zdaniem - uniwersalne zasady funkcjonowania ludzkiego umysłu, które w filozofii nazwano myśleniem, a samo myślenie zostało uznane za zasadę systemową. Myślenie i działanie są podstawowymi formami realizacji człowieczeństwa.

Podstawową relacją w sferze uniwersalnych zasad funkcjonowania ludzkiego umysłu jest relacja między myśleniem i działaniem, którą Florian Znaniecki oddał jako: „każde działanie jest myślą" i „każda myśl jest działaniem”. Działanie bowiem zachodzi tylko tam, ,gdzie przebieg idealny jest czynnikiem wywołującym i organizującym fakty realne” (Znaniecki 1922: 104-105). Jest zatem działanie procesem myślowym, który powoduje konsekwencje fizyczne, czyli jest takim aktem idealnym, który wywołuje realne skutki w świecie zewnętrznym dostępnym dla doświadczenia innych podmiotów.

Myślenie o człowieku zakorzenione jest w koncepcji ludzkiej natury, a najlepszym tego dowodem jest myślenie o człowieku, które obecne jest w spuściźnie po Leszku Kołakowskim. Jego wiara w Rozum i Człowieka pojawia się już w pracy z 1958 roku zatytułowanej Jednostka i nieskończoność. Wolność i antynomie wolności w filozofii Spinozy, w której opowiedział się za „figurą wyzwolenia samotniczego”. Oznacza ona autonomię indywidualną ufundowaną w Rozumie. Filozof twierdzil, że nie ma dobrych wyborów - stoimy przed antynomią, której nie da się przechytrzyć. Albo wybieramy autentyczność idei, wierność naszym aspiracjom - i pozostajemy bezsilnymi marzycielami, albo opowiadamy się za skutecznością i wpadamy w pułapkę instytucji, która prowadzi nas do zdrady wartości, z jakich nasza działalność czerpie usprawiedliwienie. Pomimo różnych intelektualnych zawirowań Kołakowski pozostał tej figurze wierny. Urok jego prac na tym przede wszystkim polega, iż są one nie tylko dobrymi i interesującymi pracami z zakresu historii idei, lecz także ciekawymi i inspirującymi komentarzami do współczesności. W kontekście „figury wyzwolenia samotniczego" to pojęcie absolutu, podobnie jak wiele innych kategorii filozoficznych, jest pojęciem obciążonym wewnętrzną sprzecznością, które jako takie nie może stanowić fundamentu niczego, co niekwestionowane. Paradoks relatywistów i zwolenników absolutu polega bowiem na tym, że relatywiści mają rację z absolutystycznych powodów, i vice versa.

Tak jak Kołakowski w swoim myśleniu o kulturze uzależnił się od absolutu, tak Zygmunt Bauman uzależnił się od praxis. Wedle Dariusza Brzezińskiego: „Aksjologiczny fundament myśli Marksa Bauman utożsamiał - tak wówczas, jak i przez kolejne lata swej twórczości - z podejmowaniem działań mających na celu usunięcie niesprawiedliwości społecznej, fetyszyzmu towarowego oraz wszelkich form zawłaszczania ludzkiej podmiotowości" (Brzeziński 2017: 20).

To uzależnienie zawdzięczał Antoniemu Gramsciemu, który pisał: „Cóż może przeciwstawić klasa nowatorska temu gigantycznemu kompleksowi szańców i fortyfikacji klasy panującej? Musi mu przeciwstawić ducha rozłamu (spirit di scissione), czyli stopniowe zdobywanie świadomości własnej osobowości historycznej, ducha rozłamu, który powinien dążyć do rozszerzania się klasy przodującej na klasy, które są jej 
potencjalnymi sprzymierzeńcami (...)” (Gramsci 1961: 429). Gramsci był przekonany o prymarnej roli kultury w zakresie przeprowadzania zmiany społecznej.

O filozofii praktyki autor Płynnej nowoczesności pisał: „(...) może ona sama stać się więc światopoglądem większości tylko w jeden sposób, przezwyciężając «rozum potoczny», ukazując rzeczywistą strukturę procesu społecznego, doprowadzającą do świadomości mas dialektyczny związek między działaniem człowieka a historią jego społecznego świata” (Bauman 1996: 121). Bez wątpienia przezwyciężanie „rozumu potocznego” to zadanie socjologii, w ramach której szczególna rola przypada pracy socjalnej.

Tym, co łączy Kołakowskiego i Bauman w ich namyśle nad kulturą europejską, jest model pojęciowy wypracowany na gruncie antropologii i - co ważniejsze - stanowiący ukoronowanie kilku dziesięcioleci rozwoju tej dyscypliny. Jest to model strukturalistyczny w wersji nieortodoksyjnej, wywiedziony z prac Claude’a Lévi-Straussa. O modelu tym można powiedzieć wiele, przede wszystkim jednak to, że jest on ucieleśnieniem relatywizmu i otwartości, niepewności i „odmowy przyjęcia jakiejkolwiek identyfikacji zakończonej”, słowem - „ducha europejskości”. Kołakowski po raz pierwszy ów model zaprezentował w pracy z roku 1965 Świadomość religijna i więź kościelna:

Sens zjawiska, które bierzemy za centrum struktury - pisze - może być wzbogacany nieograniczenie
przez włączenie do struktury nowych rodzajów zależności i nigdy nie mamy prawa oznajmić, że
w jakiejś rekonstrukcji został wyczerpany bez reszty. W tym znaczeniu struktura pozostawia zawsze
miejsce otwarte i nie ma żadnego powszechnie ważnego kodeksu, który by pewne rodzaje zależności
z góry wykluczał albo obkładał zakazem; żadnej a priori ważnej zasady, mocą której jakiś typ związków
byłby bezużyteczny dla zrozumienia zjawiska czy zgoła zrozumieniu jego przeszkadzał.

I dalej:

Sensowność faktu pozostaje tedy dla wiedzy w stanie chronicznej tymczasowości, ponieważ każdy sens nadany - a sensowność nie jest immanentną jakością faktu, ale jego miejscem w zrekonstruowanych całościach - jest sensem otwartym ze względu na możliwość zmiany struktury przez włączenie faktów nowych (Kołakowski 1965: 39, 506-561).

Bauman odwołał się do tego modelu w Szkicach z teorii kultury, które były gotowe do druku w roku 1968 (ze względu na wydarzenia w marcu tegoż roku nie zostały wydane). Potraktował kulturę jako mechanizm redukcji wieloznaczności - jest ona ciągłym, niekończącym się procesem, dzięki któremu rzeczywistość kulturowa ulega permanentnym zmianom.

Autor Myśli nieoswojonej był teoretykiem kultury i wierzył w immanentny ład pośród zamętu. Tym ładem jest myślenie. Wystarczy sięgnąć do założeń jednomyślnie uznawanych przez ewolucjonistów w antropologii społecznej, aby mieć jasność, że poszukiwanie uniwersalnych reguł funkcjonowania ludzkiego umysłu było kontekstem odkrycia i uzasadnienia poznania antropologicznego. Tym, co różni podejście Lévi-Straussa od podejścia typowego dla ewolucjonistów, jest wyjście z pułapki europocentryzmu. 
Ewolucjoniści pytali: dlaczego dzicy pozostali w tyle, skoro istnieją uniwersalne zasady funkcjonowania ludzkiego umysłu? Ich odpowiedź była prosta: wszyscy skazani jesteśmy na postęp i musimy przejść te same stadia, chociaż w innym czasie, ponieważ oś czasu leżąca u podstaw konstrukcji ewolucjonistycznych jest uniwersalna.

Autora Smutku tropików - tak jak antropologów ewolucjonistów - nie fascynowało zróżnicowanie kulturowe, ale podobieństwa i „niezmienniki” w życiu społecznym, czyli uniwersalia. Jednym z tych niezmienników jest myślenie mityczne - „myśl nieoswojona”, którą Kołakowski nazwał stałą obecnością mitu w kulturze. Obaj myśliciele wierzyli w to, że myślenie jest nałogowo strukturalistyczne. Po prostu myślimy pojęciami, które są w relacji symetrii przeciwieństw. W Historie de Lynx (Opowieści o rysiu), która jest syntezą badań mitów amerindiańskich, Lévi-Strauss stawia tezę dualistycznej koncepcji przyrody, przy czym indiański dualizm nie jest tożsamy z dualizmem Heglowskim tezy i antytezy. W tym indiańskim dualizmie dwie części nigdy nie są równe, nigdy nie znajdują się w stanie równowagi, dlatego też możemy mówić o silnych i słabych. Być może ten indiański dualizm jest odpowiedzialny za to, że 20 tysięcy uzbrojonych Inków stanęło jak sparaliżowani na widok 160 Hiszpanów, a Aztekowie padli na twarz przed Cortezem.

Lévi-Strauss w rozmowie z Antoin’em de Gaudemarem formułuje tezę, że myśl mityczna odgrywa różne role, zależnie od epoki, ale zawsze jest niezastąpiona, a mity mają twardy żywot: wracają tam, gdzie ich się najmniej spodziewamy, czyli mówiąc językiem teoretyka kultury europejskiej - L. Kołakowskiego - mity są stale obecne w każdej kulturze. W Myśli nieoswojonej opublikowanej w roku 1962 odkrył on, że nie ma nic absurdalnego w stwierdzeniu, iż świat jest absurdalny, a za kategoriami "my” i „sens” mamy „nicość” i „bezsens”. Tym samym przyznał rację egzystencjaliście Jeanowi-Paulowi Sartre’owi, który w pracy Byt i nicość pisał, że byt jest przejawem nicości. A zgodnie z poglądami Benedykta Spinozy czas - pojęty jako następstwo zdarzeń - jest rezultatem niedoskonałości naszych zmysłów. Istnieje wieczne teraz, co potwierdza mit jako narzędzie do unieruchamiania czasu właśnie. Bauman, pisząc o dekonstrukcji linearnej temporalności, twierdzi, że: „Czas jest rzeką bez koryta, potokiem, który żłobi swą trasę, płynąc, niepewny zlewiska, do jakiego zmierza. Czas nie jest jak niegdyś, wektorem - jest pędem bez strzałki kierunkowej” (Bauman 1995: 19). W płynnej ponowoczesności „teraz” jest miejscem szczęścia - jego jedynym miejscem. „Czas życia rozłożony został na następujące po sobie takie «teraz», a każde z nich wcale nie jest mniej znaczące niż inne, każde w równym stopniu zasługuje na to, by je przeżyć w pełni, w pełni się nim bawić, całkowicie wycisnąć z niego wszystkie osładzające życie soki” (Bauman 1998: 231).

Największym paradoksem współczesności jest odrzucenie w dzisiejszej kulturze europejskiej pojęcia zła jako czegoś realnego i suwerennego, i umiejscowienie go w takich bytach, jak: „czarownice”, „Żydzi”, „religijni fundamentaliści”, „terroryści” itp. Żyjemy w iluzji przypadkowości zła. Człowiek - dzięki niezwykłym technologicznym osiągnięciom - oszukuje sam siebie, że wyemancypował się od swej przygodnej nędzy, a najważniejsi aktorzy życia społecznego nadal toczą ze sobą walkę nie tylko o dobra 
materialne i władzę, lecz także o mity i symbole. Ich kontrola umożliwia bowiem manipulacje ludzkimi emocjami i panowanie nad zbiorową wyobraźnią.

L. Kołakowski w Kompletnej i krótkiej metafizyce... pisze, że oprócz śmierci wszystkie zakończenia są pozorne. Śmierć jest jednym z czterech filarów domu, którego sklepieniem jest Czas, rzeczywistość najpospolitsza w świecie i najbardziej tajemnicza. Zatem śmierć jest końcem tej czasowości, w której byliśmy zanurzeni. Jest narzędziem, za pomocą którego uwalniamy się od przerażającej rzeczywistości czasu, by go prawdziwie oswoić.

Bauman swoje odczytanie Lévi-Straussa wpisuje w ramy wiary autora Myśli nieoswojonej w to, że zadaniem antropologa jest rozpoznawanie „inności” jako inności właśnie, w jej wewnętrznej „prywatnej” logice, niezbrukanej natręctwem myśli wyhodowanej w retoryce obcej cywilizacji. Nazywa go „wielkim rewolucjonistą ludzkiej samowiedzy”, a potencję uspołecznienia trafnie lokuje w naturze ludzkiej (Bauman 2017: 58-60).

Dzięki językowi, pojęciom abstrakcyjnym, myśleniu - człowiek może tworzyć myślnie struktury świata - nie niszcząc obiektu, który struktury te mają odwzorowywać. (...) Za sferą zjawiskową tkwią nie tyle potrzeby jednostkowe bądź zbiorowe, co struktury. Struktura jest istotą kultury. Zrozumieć kulturę - to tyle, co za wyspecjalizowanymi technologicznie sferami ludzkiej działalności wykryć wspólnotę struktury myśli ludzkiej; ducha ludzkiego. (...) antropologia nie jest nauką o instytucjach, obyczajach, lecz o strukturze myśli ludzkiej, ujawniającej się w nich. (...) Ta struktura jest dla gatunku ludzkiego w zasadzie jednaka. Różnią się tylko jej uprzedmiotowione wyrazy. (...) Wspólnota ludzkiego gatunku zasadza się na skończoności zbioru struktur znaczących, wśród których poszczególne systemy kulturowe mogą wybierać - zawsze posługując się jednak podobnymi zasadami konstrukcyjnymi, co pozwala właśnie rozpatrywać każdą strukturę jako transformacje innej struktury, choćby związanej ze społeczeństwem, którego o kontakt fizyczny ani teraz, ani w przeszłości podejrzewać nie można (Bauman 2017: 62-64).

Badacz stwierdza, że dla autora Myśli nieoswojonej „faktem ostatecznym” w świecie spraw ludzkich jest konstrukcja myśli ludzkiej, sposób budowania struktur intelektualnych, odtwarzających lub projektujących alternatywy ludzkiego istnienia. Stawia strukturalizm wobec trudnego pytania: wobec jakiej rzeczywistości kultura pełni funkcje znakową? I odpowiada na nie z perspektywy aktywistycznej i materialistycznej: funkcja kultury polega na redukowaniu nieoznaczoności świata, to jest eliminowaniu szeregu potencjalności oraz ukazywaniu określonych wyborów jako właściwych i oczywistych. Kultura polega na przekształcaniu tego, co nieprzepowiadalne, w to, co konieczne. Kultura jest więc tworzeniem informacji, procesem wysycania informacją zewnętrznego i wewnętrznego środowiska człowieka. Pełni funkcje poznawczą i sterowniczą zarazem. Kultura jest sposobem porządkowania, strukturalizowania otoczenia jednostki ludzkiej i sposobem korelowania porządku jednostkowego zachowania się z porządkiem owego otoczenia. Świat staje się językiem w miarę tego, jak ludzie uczą się wydobywać zawartą w zjawiskach informację. Funkcja informacyjna działań ludzkich, jak wszelka funkcja informacyjna, polega na zmniejszaniu nieoznaczoności sytuacji. Im 
większa nieoznaczoność sytuacji społecznej, tym większy musi być ładunek informacyjny działań ludzkich dla niej właściwych, aby umożliwić prawidłową orientację. Gatunek ludzki nieustannie znosi nieoznaczoność swego świata, ale osiąga to, czynnie ten świat porządkując.

Kultura przekształca amorficzny chaos w układ prawdopodobieństw przewidywalny i manipulowalny zarazem - przewidywalny przez to właśnie, że manipulowalny. Chaos doznań przekształca w spójny system znaczeń, a zbiór jednostek - w system społeczny o trwałej strukturze. Kultura to tyle, co likwidacja nieoznaczoności sytuacji ludzkiej (lub w każdym razie jej redukcja) przez wyeliminowanie jednych możliwości na rzecz drugich (Bauman 2017: 64).

W poszukiwaniu struktur elementarnych myślenia-działania, czyli ludzkiej praxis, która jest rzeczywistą cechą gatunkową człowieka, sięgać wypada zarówno do dokumentów ustnych i pisanych ludzkiego myślenia, jak i do zmaterializowanych punktów wyjścia i zarazem produktów tego myślenia, czyli sposobów praktycznego porządkowania ludzkiego świata. „Świat człowieka i jego myślenie mają strukturę izomorficzną, i ta wspólna struktura odciska się także na obu aspektach kontaktu człowiek-świat: na ludzkim działaniu i na ludzkim myśleniu. Siedliskiem powszechników kulturowych jest kultura jako całość" (Bauman 2017: 162).

Autor Szkiców z teorii kultury, wychodząc od tezy Lévi-Straussa, że wszelka klasyfikacja jest przezwyciężaniem chaosu, tworzy kategorię „nieoznaczonych marginesów kulturowych w oznaczonym świecie”.

Otóż wydaje się nam, że zjawiskami zasługującymi na osobne wyróżnienie i na osobne miano marginesu są te obszary, których cechą szczególną nie jest brak, lecz właśnie nadmiar kulturowych znaczeń. Objęte przez znaczenia kulturowe, są one w pełni dostępne postrzeganiu ludzkiemu, identyfikowalne, zmysłowo i wyobrażeniowo uchwytne. Ale zarazem nie mają jednolitego znaczenia, ściślej mają równocześnie rozmaite znaczenia, i to znaczenia wzajem sprzeczne. Są więc nie tyle oznaczone, co nadmiernie oznaczone. Osiągają ten nadmiar oznaczoności, która owocuje na iście heglowski sposób nieoznaczonością wyższego stopnia, nierozwiązywalnym, nękającym, niepokojącym zadaniem pogodzenia tego, czego pogodzić się nie da (Bauman 2017: 108).

Muszą zatem prowadzić do proliferacji ambiwalencji. Redukcja wieloznaczności jest ciągłym, niekończącym się procesem, dzięki któremu rzeczywistość kulturowa ulega permanentnym zmianom. Najistotniejsze znaczenie w rozważaniach nad kulturą ma rozpad jej systemowych własności, którego pochodną jest proliferacja ambiwalencji.

W tym kontekście istotna jest uwaga mówiąca o tym, że regulacja normatywna, stanowiąca uprzednio domenę państwa, została zastąpiona obecnie praktyką „uwodzenia", realizowaną przez instytucje rynkowe. To wzmocniło bezpośrednią zależność między rozwojem kultury konsumpcyjnej a powiększaniem się obszarów nędzy oraz ubóstwa i wygenerowało podział na grupę osób „uwiedzionych” i represjonowanych. 
Wybrakowani konsumenci są całkowicie bezużyteczni, niepotrzebni, sami stanowią problem do rozwiązania.

Mamy dwa rodzaje mechanizmów ochronnych stosowanych przez systemy kulturowe: „antropofagię" - zasadzającą się na asymilacji obcości, a także „antropoemię” - polegającą na jej odrzuceniu i wykluczeniu. Największe zagęszczenie zjawisk marginalnych, zarazem największą rolę w kulturze grających, występuje na styku sfery „ja” ze sferą "nie-ja” i na styku sfery „swojskości” ze sferą „obcości”. Doniosła społecznie sfera tabu ulokowana jest na granicy sfer „swojskości” i „obcości”. Sfera „swojskości” może być traktowana jako roztwór kulturowego pojęcia „ja”. Jest to obszar, z którym się identyfikuję, w którym jestem u siebie, który nie tylko eksploatuję, ale i kultywuję. Reszta, która pozostaje po wycięciu sfery swojskości, jest dla odmiany roztworem kulturowego pojęcia „nie-ja”. Jest to coś, co jest określone przez przeciwstawienie się mnie, przez zaprzeczenie tego, co wiem i myślę o sobie. Pojawienie się obiektu, który łączy obie te kulturowe charakterystyki, powołuje do życia nieoznaczoność, której zlikwidować się nie da. Jest to obszar definicyjnej nieomal nieprzewidywalności, wobec której jesteśmy bezbronni; nie wiemy, jak zachować się powinniśmy, aby wzbudzić pożądaną sekwencję zjawisk, brak nam jednoznacznego wzoru postępowania, obszar wymyka się wyraźnie naszej władzy. Jesteśmy wściekli i przerażeni równocześnie. Ludzie marginesu połączeni są nadrzędną cechą wspólną: są kulturowo wieloznaczni, i to wieloznaczni w sposób nieredukowalny. Instytucja tabu pozwala do pewnego stopnia wyeliminować oddziaływanie „marginesów kulturowych”.

Jak pisze Anna Kapusta:

Bez fundamentalnego dla człowieka odkrycia „Inności” nie istnieje żadne doświadczenie podmiotowości: ani indywidualnej, ani zbiorowej. Nigdy i nigdzie nie zaistniałoby żadne społeczeństwo, gdyby nie „Inność”, czyli świadomość znaczącej różnicy pomiędzy „ja” i „nie-ja”. (...). „Inność” to istotna dystynkcja, czyli społecznie definiowana różnica (Kapusta 2011: 87).

Autorka traktuje „Inność” jako cechę relacyjną, która zawiera w sobie potencjał ambiwalencji, podobnie jak tabu.

Tabu jest po prostu specyficzną, społeczną relacją nadawania cechom i ich nosicielom (osobom lub zjawiskom) statusu odrębności. Tak jak „Inność” ma ono społeczny sens jako cecha opozycyjna wobec tego, co odmienne od „nie-ja”, czyli znaczy w ludzkim horyzoncie poznawczym opozycji binarnej, która jest podstawową strategią orientowania się w świecie (Kapusta 2011: 90).

W konkluzji autorka stwierdza, że w ponowoczesności dobrze socjalizowana jednostka musi nauczyć się „Inności” innych ludzi po to, aby móc trafnie zdiagnozować własną „Inność”. Tak rozpatrywana „Inność” koreluje z konieczną nową ekonomią inkluzji społecznej, która polega na strukturalnym wymogu innowacyjności i adaptacji do zmiany społecznej. Trening doświadczania „Inności” uczy nas wszystkich satysfakcji bycia „Innym”. 
Bezdyskusyjną zaletą antropologii słowa Waltera Onga jest wiara w dialog jako narzędzie porozumienia w pluralistycznym kontekście kulturowym. Kultura jest tym, co różnicuje; jeśli istnieje coś, co jednoczy - to jest nim biopsychiczna konstytucja gatunku ludzkiego, mechanizmy neurofizjologiczne, modyfikowane przez kulturę tylko w ich zewnętrzno-przedmiotowych wyrazach (Obirek 2010).

Takie rozumienie „Inności” dobrze współgra nie tylko z rozważaniami $Z$. Baumana, lecz także z przemyśleniami Alaina Touraine’a, który zauważa, że nie istnieje już społeczeństwo, które było przedmiotem zainteresowania socjologii i nauk społecznych. Społeczeństwo nie jest już strukturą determinującą zdolność jednostki do bycia twórcą własnej historii, czyli podmiotem działającym w pojedynkę i w grupie. Zmieniło się znaczenie instytucji; przestały one być sposobem, w jaki społeczeństwa zarządzają swoimi zasobami, tworząc programy gospodarcze, edukacyjne, kulturalne. Nauki społeczne, które znamy, umarły. Potrzebujemy nowego paradygmatu, który pozwoli dojrzeć wyłaniający się nowy świat.

Antropologia społeczna i praca socjalna okazały się „,hermeneutyką strony przeciwnej”. Osobliwość nauk społecznych na tym przede wszystkim polega, że celem socjologa czy pracownika socjalnego nie jest kumulacja przez uczestnictwo w dyskursie naukowym jak największej liczby wspólnych prawd o „obiektywnej rzeczywistości”, lecz jak najwszechstronniejsze zrozumienie, które człowiek może uzyskać, uczestnicząc w różnych kulturach. Podejmując wyzwanie zrozumienia Innego, wpływamy na badaną rzeczywistość i tym samym ponosimy odpowiedzialność. Humanistą jest ten, który uprawiając wiedzę, traktuje jej przedmioty jako obiekty świadomego działania ludzkiego, interesując się ich zawartością informacyjną, przez ludzi konstruowaną; dla którego człowiek jest zatem widzialny od podmiotowej, a nie przedmiotowej strony. Tylko taki humanista może spełniać swoją funkcję społeczną - i tylko wtedy, gdy kontaktuje się z „,niespecjalistą” za pośrednictwem sprzężeń informacyjnych, które zapewniają obustronną zrozumiałość przekazów i płynność komunikacyjną.

„Radość cywilizowanego życia - jak twierdzi Bauman - nabyć można tylko łącznie $\mathrm{z}$ cierpieniem, zadowolenie przybywa ręka $\mathrm{w}$ rękę $\mathrm{z}$ rozgoryczeniem, a poddanie się z buntem" (Bauman 2006: 7). W Etyce ponowoczesnej proponuje moralność ufundowaną w asymetrycznej relacji z Innym, Lewinasowska odpowiedzialność za Innego jest bowiem relacją społeczną, która zakłada podporządkowanie się wobec Innego. Wynika z potrzeby kształtowania osobistej - niepoddającej się uniwersalizacji - odpowiedzialności za Innego.

Zdaniem Bertranda Russella idea dobra i zła wiąże się z naszymi pragnieniami, a nasze pragnienia bywają wzajem niezgodne. Etyka jest próbą przezwyciężenia tej subiektywności. Nasze postępowanie będzie służyło interesowi społecznemu w tej mierze, w jakiej harmonizuje on z interesami indywidualnymi. „Zadaniem mądrych instytucji życia społecznego jest maksymalizacja tej harmonii; (...) Każdy system etyki jest artykulacją pragnień ludzi, którzy go akceptują" (Russell 2006: 149).

Powyższa diagnoza pokazuje, że przed pracownikiem socjalnym stają nowe wyzwania przede wszystkim poszukiwanie nowych strategii pomocowych, które będą niwelować 
kulturową wieloznaczność za pomocą programów edukacyjnych, uczących „Inności” innych ludzi po to, aby móc trafnie zdiagnozować własną „Inność”.

\section{Bibliografia}

Bauman Z. (1995). Life in Fragments. Essays in Postmodern Morality. Blackwell, Oxford-Cambridge. Bauman Z. (1996). Etyka ponowoczesna, tłum. J. Bauman, J. Tokarska-Bakir. Znak, Kraków.

Bauman Z. (1998). Śmierć i nieśmiertelność. O wielości strategii życia, tłum. N. Leśniewski. PWN, Warszawa.

Bauman Z. (2006). Płynna nowoczesność, tłum. T. Kuntz. Wydawnictwo Literackie, Kraków.

Bauman Z. (2017). Szkice z teorii kultury. Wydawnictwo Naukowe Scholar, Warszawa.

Brzeziński D. (2017). Twórczość Zygmunta Baumana w kontekście współczesnych teorii kultury. Wydawnictwo IFIS PAN, Warszawa.

Castells M. (2000). The Information Age: Economy, Society, and Culture. Blackwell, OxfordCambridge, Mass.

Castells M. (2010). Wiek informacji: ekonomia, społeczeństwo i kultura, t. I: Społeczeństwo sieci, tłum. M. Marody, K. Pawluś, J. Stawiński. Wydawnictwo Naukowe PWN, Warszawa.

Gellner E. (1995). Pojęcie pokrewieństwa i inne szkice o metodzie i wyjaśnianiu antropologicznym, tłum. A. Bydłoń. Universitas, Kraków.

Gramsci A. (1961). Pisma wybrane, t. II, tłum. B. Sieroszewska. „Książka i Wiedza”, Warszawa. Kapusta A. (2011). Inna „inność. Doświadczenie niepełnosprawności jako kapitał kulturowy. „Z «Innej» perspektywy”, Kraków.

Kołakowski L. (1958). Jednostka i nieskończoność. Wolność i antynomie wolności $w$ filozofii Spinozy. PWN, Warszawa.

Kołakowski L. (1965). Świadomość religijna i więź kościelna. PWN, Warszawa.

Kołakowski L. (1984). Czy diabeł może być zbawiony i 27 innych kazań. Aneks, Londyn.

Obirek S. (2010). Uskrzydlony umysł. Antropologia słowa Waltera Onga. Wydawnictwo Uniwersytetu Warszawskiego, Warszawa.

Russell B. (2006). Religia i nauka, tłum. B. Stanosz. Instytut Wydawniczy „Książka i Prasa”, Warszawa.

Znaniecki F. (1922). Wstęp do socjologii. Wydawnictwo Naukowe PWN, Poznań. 